Agnieszka Stepkowska

Wyższa Szkoła Jezyków Obych im. Samuela Bogumita

Lindego, Poznań

\title{
POLITYKA JĘZYKOWA \\ W ZAKRESIE NAUCZANIA \\ PIERWSZEGO JĘZYKA \\ OBCEGO W WIELOJĘZYCZNYM \\ KRAJU NA PRZYKłADZIE \\ SZWAJCARII - INSPIRUJĄCE DOŚWIADCZENIA
}

\begin{abstract}
The article analyses the Swiss language policy, language planning and the partner - language model offered by the Swiss educational system. The Swiss language policy is most focused on extra-linguistic aims dealing with the changes in the social distribution of languages, and the promotion of multilingualism. Switzerland oscillates between two systems: the traditional language - partner model, and the choice of a language of wider communication (English). Much is indicative of the fact that now Switzerland is getting ready for multilingual future with English at hand.
\end{abstract}

\section{Wprowadzenie}

Prowadzenie skutecznej polityki językowej musi uwzględniać zasięg i czas realizacji powziętych celów. Nie tylko same decyzje, ale także i ich skutki będa wpływały na większość dziedzin życia obywateli. A więc nie będzie to tylko szkoła, która jest pierwszym i podstawowym miejscem realizacji celów polityki językowej, ale także kręgi rodzinne, miejsce pracy oraz kontakt ze światem zewnętrznym w znaczeniu ponadkrajowym. Skutki decyzji językowych o charakterze oficjalnym przenikają zatem do poziomu kontaktów indywidualnych. Ponadto, czas realizacji celów polityki językowej musi być liczony w latach, gdyż charakter i skala oddziaływania polityki językowej nie pozwalają na rzetelną ocenę $\mathrm{w}$ krótszym czasie. Należy też dodać element ryzyka, który zakłada cele niezreali- 
zowanie, w tym inne nieprzewidziane czynniki dotyczące zjawisk pozajęzykowych i społecznych, takich jak na przykład migracja ekonomiczna. Biorąc pod uwage powyższe, polityka językowa bez wątpienia stanowi wyzwanie dla każdego rządu i w każdym kraju. W sposób zrozumiały staje się ona tym większym wyzwaniem tam, gdzie mamy do czynienia z oficjalną wielojęzycznością. Społeczny rozkład języków odzwierciedla ich podział pod względem funkcji, a pośrednio także różnice w dostępie do władzy poszczególnych grup społecznych.

Niniejszy artykuł jest próbą analizy dobrego wzorca w szerokim temacie polityki językowej. Wydaje się, że spośród wielu kandydatów najlepiej posłuży nam Szwajcaria z uwagi na jej najbogatszą oficjalną wielojęzyczność na poziomie społecznym, bo dotyczącą aż czterech języków¹. Mimo, że Szwajcaria nie jest jedynym wielojęzycznym państwem w Europie, to jednak najprawdopodobniej w tym kraju wielojęzyczność realnie się praktykuje, w ramach i poza strukturami parlamentu federalnego (Watts, 1997). Kwestie językowe nie zostały upolitycznione, tak jak stało się to w przypadku Belgii. Ponadto, żadna entnolingwistyczna grupa nie urosła w siłę na tyle, by pozostałe grupy językowe przez nią marginalizowane, musiały uczyć się języka grupy dominującej, a nie odwrotnie. Szwajcarski ideał polityki chce sprzyjać utrzymywaniu wielojęzyczności poprzez równe traktowanie języków oficjalnych i ochronę mniejszości językowych. Dodatkową kwestia, którą, jak sądzę, od pewnego czasu należy brać pod uwage w odniesieniu do wielojęzyczności w Szwajcarii, stał się także język angielski. Angielski rozprzestrzeniający się bez precedensu na świecie i w Europie nie zatrzymał się na szwajcarskich granicach. Pojawienie się angielskiego w szwajcarskiej rzeczywistości nie tylko wpłynęło na skład jej wielojęzyczności, ale również przetasowało wewnętrznie kolejność samych języków. Coraz więcej wskazuje na to, że stosunki między „,szwajcarskimi” językami nabierają hierarchicznego charakteru, sprawiając, że niektóre z nich stają się równiejsze od innych. Są też takie obszary, gdzie żargon angielskiego stał się dominujący, a więc Szwajcarzy mówiący różnymi językami, lub też nawet z tego samego obszaru językowego, rozmawiaja ze sobą po angielsku (Dürmüller, 1992). W poniższych rozważaniach język angielski nie może być całkowicie pominięty, choć to nie on jest głównym tematem niniejszego artykułu. Tematem tym jest polityka językowa w wielojęzycznym kraju, a w szczególności planowanie języka. Bliższe przyjrzenie się Szwajcarii pod tym względem uświadamia, że pielęgnowanie wielojęzyczności jest głównym celem polityki językowej tego kraju. Realizacja owego celu opiera się na tzw. Zasadzie Terytorialności, czyli przypisaniu danego języka do konkretnego terytorium. Dalej, skupię się na planowaniu języka poprzez pryzmat modelu szwajcarskiego, który zakłada określoną kombinację nauczania języków

\footnotetext{
${ }^{1}$ Belgia ma dwa oficjalne języki, francuski i holenderski, oraz niemiecki obowiązujący w jednym tylko regionie; natomiast Luksemburg, choć oficjalnie trójjęzyczny z germańskim dialektem Lëtzebuergesch, a także $z$ niemieckim i francuskim, to jednak nie w tradycyjnie rozumianym sensie.
} 
partnerskich w szkołach w takim stopniu, aby komunikacja wewnątrzkrajowa była możliwa przynajmniej w stopniu podstawowym. Na koniec, okazuje się, że rozdźwięk pomiędzy teoretycznymi założeniami a rzeczywistością związany z kształceniem językowym wcale nie musi być miarą porażki, ale elementem wkalkulowanym w większy plan.

\section{Polityka językowa w wielojęzycznym kraju}

Według Steinberga (1996), Szwajcaria jest jedyna w swoim rodzaju nie z tego powodu, że ma cztery narodowe języki, ale dlatego, że to sam język zajmuje szczególne miejsce w Szwajcarii. Język jest zarówno częścia, jak i zaprzeczeniem szwajcarskiej tożsamości. Ponad wszystko, potęguje on już i tak ogromną różnorodność na terytorium tego niewielkiego kraju. W rezultacie, trudno mówić o Szwajcarii ogólnikami. Wydaje się, że trzy języki o równym oficjalnym statusie to maksymalna liczba umożliwiająca relatywnie bezproblemowe komunikowanie się w społeczeństwie. Cztery oficjalne języki lub więcej prowadzą do przeciążenia w funkcjonowaniu codziennych spraw administracyjnych i prawnych, albo też uczyni je nieskutecznymi (Kloss, 1966). Federacja szwajcarska uznaje zatem trzy urzędowe języki - niemiecki, francuski i włoski. Są to zarazem języki narodowe, do których jako czwarty zalicza się też język retoromański. Szwajcarzy maja prawo zwrócić się do władz federalnych w dowolnym języku urzędowym. Wszystkie ważne ogłoszenia, publikacje, albo akty prawne ukazują się w trzech oficjalnych językach, a czasem zdarza się też, że i w retoromańskim. Wspomniana już zasada terytorialności (Territorialprinzip) nie tylko chroni tradycyjne stosunki językowe w danym regionie, ale również obliguje kantony do zapewnienia ich nienaruszalności językowej. Jeśli więc niemieckojęzyczny Szwajcar przeniesie się do kantonu francuskojęzycznego, to będzie zobowiązany do podporządkowania się zasadzie terytorialności, która stoi wyżej od jego indywidualnego prawa do swobody językowej. Pozostaje mu jak najszybsze podjęcie nauki języka francuskiego po to, by uczestniczyć w życiu publicznym i komunikować się z władzami (Bańbuła, 1998; Szulc, 1999).

Polityka językowa jest szerokim całościowym terminem odnoszącym się do decyzji o prawach i dostępie do języków, oraz do ról i funkcji poszczególnych języków i ich odmian w państwie (Phillipson - Skutnabb-Kangas, 1996). Polityka językowa może być też postrzegana jako sposób rozwiązywania problemów komunikacyjnych. Sposoby rozwiązywania tychże problemów można dalej sklasyfikować jako pozajęzykowe, półjęzykowe i językowe. Szwajcarska polityka językowa najwięcej uwagi zdaje się skupiać na realizowaniu celów pozajęzykowych, czyli na ewentualnych zmianach w rozkładzie języków oficjalnych. Promuje zatem pluralizm językowy, współistnienie języków na równych zasadach (Blount - Sanches, 1977; Daoust, 1997).

Nauka drugiego języka oficjalnego odbywa się w duchu powszechnego interesu narodowego. System szkolnictwa w Szwajcarii jest silnie zdecentralizo- 
wany i w poszczególnych kantonach może się bardzo różnić, choć łączy je federacyjny obowiązek nauki drugiego języka oficjalnego (Schmid, 2001). Podstawowa idea polega na tym, że każdy Szwajcar, oprócz swojego języka ojczystego, powinien poznać drugi język oficjalny w stopniu aktywnym i pasywnym, oraz powinien przynajmniej rozumieć trzeci język oficjalny swojego kraju. Jednocześnie podkreśla się potrzebę znajomości innych języków obcych. Nauka pierwszego języka obcego jest obowiązkowa dla wszystkich uczniów, przy czym trzeba pamiętać, że nie może ona dotyczyć wyboru pomiędzy językiem oficjalnym a angielskim. W większości kantonów nauka drugiego języka urzędowego, czyli pierwszego języka obcego, rozpoczyna się pod koniec szkoły podstawowej, w czwartej lub piątej klasie (z uwzględnieniem szczególnych sytuacji w dwóch kantonach: trójjęzycznej Gryzonii i włoskojęzycznego Ticino). I tak, utrzymywanie wielojęzyczności złożonej z konkretnych języków wymaga realizowania określonych kombinacji nauczania języków. Według założeń przedstawionych przez Widmera et al. (1987: 27-58) wygląda to tak, że wszyscy uczniowie uczą się drugiego jezylea narodowego. Drugim jezzykiem narodowym (a przez to pierwszym językiem obcym) dla trzech grup językowych Szwajcarów - francuskiej, włoskiej i retoromańskiej - jest niemiecki; z kolei największa grupa językowa, którą stanowią niemieckojęzyczni Szwajcarzy jako swój drugi język opanowuje francuski. Natomiast pierwszym językiem obcym dla Szwajcarów włoskojęzycznych jest najczęściej niemiecki, a drugim język francuski, lub odwrotnie (także Pap, 1990; Watts, 1997). Wszyscy uczniowie uczą się trzeciego jezylka oficjalnego w takim stopniu, by go rozumieć. W przypadku trzeciego języka oficjalnego, lub drugiego języka obcego, z reguły będzie to język włoski, choć w ostatnich latach jest on prawie całkowicie wypierany przez angielski, do którego nauki motywacji Szwajcarom nie brakuje (patrz punkt 5 artykułu, Dürmüller, 1986, 1991, 1992, 1994). Podczas obowiązkowej nauki w szkole, uczniowie muszą nabyć zdolności, które umożliwią im dalsze samodzielne pogłębianie znajomości języka.

Szwajcarska polityka językowa dba o wielojęzyczność, której utrzymanie uniemożliwia pojedynczym językom wyjście na pozycję dominująca, co w konsekwencji stwarza optymalne warunki dla funkcjonowania mniejszości językowych. Z drugiej jednak strony, taki kształt polityki językowej nie powinien być postrzegany jako celowe utrudnianie obywatelom nawiązywania kontaktów międzynarodowych. Dlatego też rozpowszechnienie się angielskiego na świecie należy rozumieć jako szansę w lepszym komunikowaniu się także dla Szwajcarii (Dürmüller, 1994).

\section{Planowanie języka}

Istotną częścią polityki językowej jest planowanie języka - termin, który od czasu kiedy ukazał się u Haugena (1959), poszerzył swoje znaczenie by objąć wszelkiego typu działania interwencyjne zajmujące się problemami socjolingwistycznymi. W bardzo ogólnym ujęciu, Haugen (1972) uważa planowanie za działanie człowieka, które wynika z potrzeby znalezienia rozwiązania dla danego 
problemu. Działanie to może mieć charakter nieformalny i doraźny, po wysoce zorganizowany i przemyślany. Działania tego mogą się podjąć pojedyncze osoby, bądź też instytucje na poziomie oficjalnym. Prawidłowy proces planowania obejmuje takie etapy jak zbieranie szczegółowych informacji, przygotowanie alternatywnego planu działania, podejmowane decyzji i ich wdrażanie.

Przeanalizowanie planowania językowego w Szwajcarii jest zajmujące co najmniej z dwóch powodów. Pierwszy to jej złożoność językowa. Mimo, iż to małe państwo ma nieco ponad 7 milionów mieszkańców, obowiązują w nim trzy języki o statusie oficjalnym, albo cztery o statusie narodowym. Ponadto, to zróżnicowanie językowe spotęgowane jest faktem kultywowania przez znaczącą część populacji wielu odmian dialektów alemańskich wzajemnie zrozumiałych i występujących przede wszystkim w formie mówionej, oraz pięciu odmian w ramach języka retoromańskiego, które już takiej komunikacji nie umożliwiaja. Na całym obszarze niemieckojęzycznym Szwajcarii dialekty alemańskie dominują w codziennym użyciu, natomiast forma pisana oraz pewne sytuacje oficjalne zarezerwowane są dla standardowego języka niemieckiego (Porębski, 1994; Szulc, 1999). To zróżnicowanie funkcji poszczególnych odmian językowych charakterystyczne jest dla zjawiska dyglosji, opisanego po raz pierwszy przez Fergusona (1959). Drugim powodem, dla którego warto przyjrzeć się planowaniu językowemu w Szwajcarii jest to, że pomimo tak dużej złożoności i różnorodności językowej, trudno byłoby wskazać jedną oficjalną instytucję zajmującą się planowaniem języka. Dla Phillipsona i Skutnabb-Kangas (1996), w wielodialektowym i wielojęzycznym świecie planowanie języka jest koniecznością. Co więcej, jest ono wyrazem politycznych i ekonomicznych wyborów oraz sądów wartościujących ze strony tych, którzy planuja. Istotnie, trudno byłoby znaleźć przykład planowania językowego, którego jedynym celem byłoby poprawienie komunikacji, lub gdzie problemy komunikacyjne byłyby jedynymi do rozwiązania, lub też gdzie ułatwienie komunikacji byłoby jedynym aspektem wartym promowania. W podobnym duchu co Phillipson i Skutnabb-Kangas (1996) wypowiada się również Cooper (1989: 3435). Twierdzi on, że definicje uznające planowanie języka za rozwiązanie dla problemów językowych są nie tyle błędne co raczej mylące w tym sensie, że odciagaja uwagę od rzeczywistych motywów planowania. W związku z tym proponuje on, aby o ile planowanie języka nakierowane jest na osiąganie niejęzykowych celów, bardziej pożądanie byłoby definiować je nie jako starania by rozwiązywać problemy językowe, ale raczej jako wysiłki po to, by na zachowania językowe wpływać. A zatem, planowanie języka zwykle przeprowadza się w celu osiagnięcia celów niejęzykowych, wśród których są takie jak ochrona konsumenta, wymiana naukowa, integracja narodowa, kontrola polityczna, rozwój gospodarczy, tworzenie się nowych elit lub utrzymanie starych, pacyfikacja mniejszości, oraz masowa mobilizacja narodowych lub politycznych ruchów.

Trwa debata dotycząca wyboru języków w szkołach w systemach edukacyjnych poszczególnych szwajcarskich kantonów. Wywołuje ona silne emocje, gdyż jej zakres obejmuje nie tylko status języków w życiu publicznym Szwajcarii, 
ale, być może bardziej zasadniczo, nauczanie języków w szkolnictwie publicznym (Watts, 2001). Rzecz w tym, że uczenie się języków powinno mieć charakter wzbogacający (additive) aniżeli zubażający (subtractive). W procesie nauki językowe repertuary indywidualnych osób powinny się poszerzać. Nowe języki, w tym języki o statusie lingua franca, nie powinny być opanowywane kosztem języków ojczystych (por. Skutnabb-Kangas, 2003). W 1989 roku wydano oficjalny raport na temat szwajcarskiej wielojęzyczności (Zustand und Zukunft der viersprachigen Schweiz), który zawiera raczej krytyczną ocenę wielojęzycznej komunikacji pomiędzy niemiecko-, francusko- i włoskojęzycznymi mieszkańcami Szwajcarii. Przy czterech grupach językowych, komunikacja nie może być zapewniona tylko w oparciu o powszechny dwujęzyczny repertuar. Niektóre grupy muszą uczyć się nie tylko pierwszego, ale także drugiego języka narodowego. Tylko wówczas wszyscy Szwajcarzy mają szansę ze sobą rozmawiać. Jednak dodatkowego wysiłku nauczenia się kolejnych języków oczekuje się nie od dwóch największych grup językowych, ale od najmniejszych. W odróżnieniu od niemiecko- i francuskojęzycznych Szwajcarów, ich rodacy mówiący po włosku i retoromańsku nie mają innego wyjścia jak uczyć się także drugiego języka obcego z repertuaru języków oficjalnych, tj. albo niemieckiego albo francuskiego (także Kolde, 1988). Dla nich angielski pojawia się na miejscu czwartym (jako L4) po języku ojczystym i po dwóch językach największych grup językowych. Natomiast w kantonach z językiem niemieckim i francuskim, język angielski jest wybierany jako L3, wygrywając popularnością wśród uczniów i studentów z włoskim, trzecim językiem narodowym Szwajcarii. Trzeba też wspomnieć, że jednym z czynników najbardziej ograniczających planowanie języka, także w Szwajcarii, są finanse potrzebne na realizacje tego procesu (więcej w Fasold, 1984). Wielojęzyczność wymaga nakładów publicznych i fiskalnej redystrybucji na korzyść mniejszości. W Szwajcarii istnieją także trzy kompletne sieci publicznej radia i telewizji, po jednej dla każdej z grupy językowej (Linder, 1996; Ratajczak, 2004), które są dotowane proporcjonalnie do swoich potrzeb.

\section{Szwajcarski model}

Edukacja wielojęzyczna jest $\mathrm{z}$ definicji skomplikowana. Stawia ona wyzwania w zakresie administracji, materiałów do nauczania i nauczycieli. Istnieja różne programy wielojęzycznego kształcenia w zależności od potrzeb językowych i kontekstowych oraz zasobów finansowych. Szwajcarski model dotyczący komunikacji zakłada, że każdy Szwajcar mówi językiem ojczystym i jest przez swoich innojęzycznych rodaków, z którymi rozmawia, rozumiany. Obok języka ojczystego, drugi język narodowy jest nauczany do osiagnięcia stopnia receptywnego i produktywnego, czyli umożliwiającego aktywną komunikację, natomiast w trzecim języku narodowym uczy się rozumienia (Widmer et al., 1987: 101). W szkołach nauka odbywa się przynajmniej w dwóch językach. Nauczanie drugiego języka zaczyna się już w piątej klasie (Baur, 1992). Jednak nieprawdą jest, że te 
wysiłki przekładają się na powszechną dwu- lub trójjęzyczność. Większość Szwajcarów zna tylko jeden język. Prawdopodobnie mniej niż połowa potrafi mówić lub czytać w drugim języku wykazując przy tym różny poziom biegłości. Jednak coraz częściej drugim językiem wybieranym przez większość Szwajcarów jest angielski (Pap, 1990; Watts, 1991). A zatem wewnętrzna komunikacja Szwajcarów powinna się realizować w formie tzw. Modelu Języków Partnerskich (Partnersprachmodell) (Dürmüller, 1992). Lansowane przez szwajcarską politykę edukacyjna rozwiązanie dwujęzyczne byłoby dobrym jedynie w przypadku dwóch największych grup językowych. W sytuacji kontaktu językowego, jeden z rozmówców będzie musiał wykazać się pełną znajomością (pasywną i aktywna) drugiego języka. Aby rozmowa zaistniała, jeden z dwóch dostępnych języków jest wybrany jako medium porozumienia. W kontakcie językowym między Szwajcarami mówiącymi po francusku i tymi mówiącymi po niemiecku, każdy z rozmówców może teoretycznie posługiwać się swoim językiem ojczystym (L1). Można założyć, że poziom pasywnej kompetencji w drugim języku (L2) pozwoli im na prowadzenie rozmowy. Jest to jednak założenie na wyrost, gdyż większość niemieckojęzycznych Szwajcarów nie mówi takim niemieckim, którego ich francuskojęzyczni rodacy uczą się w szkołach. Język ojczysty mieszkańców z niemieckiego obszaru językowego Szwajcarii to dialekty alemańskie, a oni sami także uczą się w szkołach standardowej odmiany języka niemieckiego.

Wewnętrzna komunikacja w wielojęzycznej Szwajcarii w formie wspomnianego Modelu Języków Partnerskich (MJP) może funkcjonować w sytuacji, gdy każdy z rozmówców będzie miał w swoim indywidualnym repertuarze do dyspozycji trzy języki narodowe. Dürmüller (1989: 5) szczegółowo przedstawia idealne kombinacje językowe w repertuarach Szwajcarów, tj. L1, L2, L3 i L4, z każdej z trzech grup języków oficjalnych, a także potencjalne 'zagrożenie' dla tychże kombinacji w postaci angielskiego zajmującego pozycję L2 u każdej z grup językowych. Aby MJP stał się rzeczywistością, szwajcarski system szkolnictwa dąży do „wyposażenia” każdego obywatela przynajmniej w podstawowa znajomość drugiego języka oficjalnego. Wynik tego przedsięwzięcia wypada różnie, a wiele osób kończących swoją edukację na poziomie średnim lub wyższym wykazuje się, w najlepszym wypadku, bierną znajomością drugiego języka oficjalnego. Takie osoby można sklasyfikować jako osoby dwujęzyczne z pasywną znajomością drugiego języka (passive bilinguals) wśród których jednak trudno o skuteczne czy swobodne porozumiewanie się na każdy temat. Dürmüller (1994) podaje, że Szwajcarzy najczęściej dorastaja jako osoby znające tylko jeden język (monolinguals), a znajomość drugiego języka nabywają w szkole. System edukacyjny w Szwajcarii pozwala też założyć, że w praktyce każdy obywatel uczęszczał na lekcje jednego języka obcego przynajmniej dwa lata. Oznacza to, że kompetencje wynikające $z$ dwuletniego (nieintensywnego) kursu językowego równają się jego pasywnej znajomości, która pozwala raczej na ograniczony kontakt językowy. Co do Szwajcarów władających trzema lub czterema językami, Dürmüller (ibid.) przedstawia dane, które wyraźnie przeciwstawiają się mi- 
towi wielojęzycznej Szwajcarii, nie tyle jako państwa, ale z perspektywy indywidualnego obywatela. Poligloci w społeczeństwie szwajcarskim stanowią raczej wyjątek aniżeli regułę. Większość trójjęzycznych Szwajcarów zamieszkuje południowe części kraju, głównie włoski kanton Ticino oraz Gryzonię. To oni są prawdziwymi poliglotami w porównaniu z tymi Szwajcarami, których L1 jest język niemiecki lub francuski. Prawdę mówiąc, wszystko wskazuje na to, że indywidualna wielojęzyczność jest odwrotnie proporcjonalna do ilościowej wielkości danej grupy językowej do której się przynależy. Ci z największych grup językowych często zadowalają się dostateczną znajomością drugiego języka narodowego. Natomiast trzeci język w ich repertuarze jest raczej rzadkościa, a nawet jeśli znają już trzeci język, to najpewniej jest to angielski, a nie którykolwiek inny z pozostałych języków narodowych. Dürmüller (1994: 225) podaje, że jedna trzecia obywateli z południowych krańców Szwajcarii ma dobrze opanowany trzeci język narodowy, a ponad połowa z nich używa go na zadowalającym poziomie. Watts (1991: 88) dodatkowo wyjaśnia taki stan rzeczy tym, że w Ticino nie ma uczelni wyższej, w której włoskojęzyczni Szwajcarzy mogliby kontynuować naukę. W konsekwencji, ci którzy chcieliby zdobyć wykształcenie wyższe stoją przed wyborem francuskojęzycznych lub niemieckojęzycznych uniwersytetów. Oznacza to, że dwujęzyczność włoskojęzycznych Szwajcarów chcących zdobyć pełne wykształcenie jest na stosunkowo wysokim poziomie.

\section{Nauka angielskiego w Szwajcarii}

Szwajcaria jest dobrym przykładem narastającego dylematu w Europie, związanego z językiem angielskim. Jesienią 2000 decyzją właściwych organów, kanton Zurych ogłosił plan wprowadzenia angielskiego jako ,pierwszego języka obcego" w miejsce francuskiego, a ściślej, redukując liczbę lekcji (Pap, 1990). Nauka angielskiego miała się rozpoczynać już w trzeciej klasie szkoły podstawowej. Posunięcie to okazało się dość kontrowersyjne i wywołało niepokój w oficjalnych kręgach. Zwyczajowo dzieci w Szwajcarii są nauczane drugiego języka narodowego jako pierwszego języka obcego. Oczekiwano, że dla niemieckojęzycznych uczniów w Zurychu będzie to francuski. Zatem angielski wszedł na pozycję nie tylko najpopularniejszego języka w szkołach, ale także języka odgrywającego znaczącą rolę w wewnętrznej komunikacji Szwajcarów i w kultywowaniu narodowej tożsamości. Uzasadnieniem dla sytuacji w Zurychu wydaje się również obecna istotniejsza rola angielskiego, jaką odgrywa on w życiu zawodowym i prywatnym niemieckojęzycznych Szwajcarów aniżeli w życiu ich francuskojęzycznych rodaków (Graddol, 2001; Grin, 1997, 1999).

W kraju oficjalnie wielojęzycznym, takim jak Szwajcaria, gdzie trzy języki narodowe są ważnymi językami europejskimi, wydawałoby się logiczne i polityczne celowe ustanowić prawo, że pierwszym 'obcym' językiem nauczanym w szkołach musi być jeden z pozostałych dwóch języków narodowych. Jednak ponieważ żaden z trzech języków, tj. niemiecki, francuski i włoski, nie jest 'obcy' 
w Szwajcarii, dla określenia każdego z nich używa się francuskiego wyrażenia 'langue nationale 2' (język narodowy 2). Wspominając o angielskim w Szwajcarii możemy sobie przypomnieć, za Prcic'em (2003: 35), trzy kryteria, które opisuja status języka obcego w następujący sposób: (1) nie jest to język ojczysty/pierwszy danego państwa, (2) nie jest to oficjalny język danego państwa, i (3) jest on nauczany w szkołach jako osobny przedmiot.

Obecność języka angielskiego w szwajcarskiej przestrzeni publicznej ulega powolnemu przeobrażeniu. W przeszłości indywidualne repertuary językowe kształtowały się prawie wyłącznie w obrębie trzech języków narodowych Szwajcarii, czy to w przypadku osób dwujęzycznych czy też, choć rzadziej, trójjęzycznych. Angielski zdecydowanie nie wchodził w skład tychże repertuarów. Był to tylko język obcy i ze względu na swój marginalny status, nie pojawiał się zbyt często w indywidualnych repertuarach (Dürmüller, 1992). Dziś angielski nie ma oficjalnego miejsca w Szwajcarii, niemniej jednak jest już w niej obecny. Nie ma żadnych przepisów, które nakazywałyby ograniczenie lub wprowadzenie zakazu języka angielskiego na szwajcarskich uniwersytetach. Ponadto, same uczelnie nie mają w tym względzie jasno określonej polityki, w konsekwencji czego, można przyjąć, że angielski wchodzi wielkimi krokami do środowisk naukowych w Szwajcarii (Dürmüller, 2001, więcej w Murray - Dingwall, 1999: 192).

Angielski jest też dobrym przykładem na rozdźwięk między oficjalnym (de iure) i faktycznym (de facto) statusem w Szwajcarii. Oficjalnie angielski jest dopuszczony w szkolnictwie jako L3 (a jako L4 we włoskojęzycznej części), jednak, przynajmniej wśród ludzi młodych, już przesunął się na pozycję L2 (Dürmüller, 1986, 1992). Z kolei, Romaine (1994: 35), odnosząc się do Szwajcarii, opisuje różnicę pomiędzy dwujęzycznością lub wielojęzycznością de iure i de facto jako tę, w której „territorial unilingualism exists under federal multilingualism” [terytorialna jednojęzyczność istnieje w ramach federalnej wielojęzyczności - tłum. moje]. Spójność państwa wymaga tego, aby jego obywatele wzajemnie się rozumieli i zakłada gruntowną znajomość więcej niż jednego języka narodowego. Zatem angielski nie powinien przeobrazić się w lingua franca Szwajcarii, choć, z drugiej strony, jego znajomość stała się nieodzowna. Dodatkowo, można się też spodziewać, że w najbliższych latach zastosowanie angielskiego nie tylko w skali międzynarodowej, ale także w skali krajowej, będzie raczej wzrastać aniżeli maleć.

\section{Uwagi końcowe}

Niniejszy artykuł przedstawił w zarysie podejście do planowania języka jako procesu decyzyjnego. Nie uważam jednak planowania jedynie za aktywność o charakterze idealistycznym i wyłącznie językowym. Planowanie języka jest też działaniem politycznym i administracyjnym skierowanym na rozwiązywanie problemów językowych w społeczeństwie, gdyż to właśnie społeczne skutki problemów językowych i społeczny kontekst niejako wymuszają zdyscyplinowane podejmowanie decyzji na temat języka na poziomie narodowym (Jernudd 
- Gupta, 1971, także Lotherington, 2004). Zgadzając się z Bourdieu (1986), powtórzę za nim, że język może podlegać planowaniu, gdyż jest on zasobem, który może być i jest oceniany. Przewidywalność skutków planowania językowego wzrasta, jeżeli uwzględnia się społeczny kontekst problemów językowych, a przede wszystkim społeczne, kulturowe i ekonomiczne siły, które przyczyniają się do zachowania języka, bądź jego przesunięcia (language shift). Nawet najlepiej przygotowana polityka edukacyjna dla grup mniejszościowych jest skazana na porażkę, jeśli jej realizacja miałaby iść pod prąd dominującym siłom społecznym, a szczególnie sytuacji gospodarczej. Wysiłki planowania języka mają szansę się powieść, jeśli zostaną wsparte przez korzyści ekonomiczne lub społeczne nakierowane na grupy mniejszościowe (Linder, 1996; Paulston, 1988).

Zaobserwowano, że Szwajcarom nie udaje się osiagać wystarczającego stopnia dwujęzyczności na poziomie ogólnokrajowym (Dürmüller, 1991, 1992). Mogłoby się wydawać, że częściowym powodem takiego stanu rzeczy jest obecność angielskiego w Szwajcarii, gdyż wysiłki skierowane na naukę L2 idą w dwóch kierunkach. Z jednej strony, uczniowie uczą się drugiego języka narodowego w szkołach, gdyż jest on tam obowiązkowy; a z drugiej strony, nauka angielskiego jest podejmowana dobrowolnie i z dużą motywacja. Angielski uważany jest za język modny, a przede wszystkim bardziej użyteczny niż którykolwiek z języków narodowych. W Szwajcarii, kraju z czterema językami narodowymi, angielski stał się nie tylko najpopularniejszym językiem obcym i językiem komunikacji międzynarodowej, ale także potencjalną lingua franca na potrzeby wewnętrznej komunikacji wśród Szwajcarów (Dürmüller, 1992, 1997). Wzrastające posługiwanie się językiem angielskim w Szwajcarii przeciwdziała wysiłkom w ramach polityki językowej nakierowanej na wspieranie wielojęzycznego dialogu wśród Szwajcarów. Można wnioskować, że decydującym czynnikiem w nauce języków nie jest wola polityczna właściwych instytucji i władz, ale konkretne potrzeby indywidualnych osób. Przypadek Szwajcarii pokazuje też, że w społeczeństwie wielojęzycznym, status języka szerszej komunikacji (Language of Wider Communication) najłatwiej może uzyskać język obcy. Mimo, że angielski jest jedynie językiem obcym w Szwajcarii, jego przewaga nad językami narodowymi tego kraju polega na tym, że jest on neutralny, przez co nie może prowadzić do konfliktów między poszczególnymi grupami językowymi. Jest on akceptowany w sytuacjach, gdzie MJP się nie sprawdza. Na ile można ocenić obecną sytuację, Szwajcaria oscyluje między dwoma systemami, tj. tradycyjnym MJP, w którym kompetencje L2 są zadowalające, a wyborem języka o szerszym zasięgu (angielski) w dziedzinach, które wymagaja specjalistycznego użycia języka. Wiele wskazuje na to, że Szwajcaria przygotowuje się na wielojęzyczną przyszłość, ale o innym niż dotychczas kształcie, tj. $z$ językami narodowymi i z angielskim w tle. 


\section{BIBLIOGRAFIA}

Bańbuła, S. 1998. O Szqwajcarii... prawie wszystko. Warszawa: Wydawnictwo SGGW. Baur, A. 1992. Szwajcarski fenomen. Warszawa: Wiedza Powszechna.

Blount, B. G., Sanches, M. (eds.). 1977. Sociocultural dimensions of language change. New York - San Francisco: Academic Press.

Bourdieu, P. 1986. „The forms of capital” (w:) J. G. Richardson (ed.). Handbook of theory and research for the sociology of education. New York: Greenwood Press: 241-258.

Cooper, R. L. 1989. Language planning and social change. Cambridge: Cambridge University Press.

Daoust, D. 1997. „Language planning and language reform” (w:) F. Coulmas (ed.). The handbook of sociolinguistics. Oxford: Blackwell: 436-452.

Dürmüller, U. 1986. „The status of English in multilingual Switzerland”, Bulletin CIL A 44: 7-38.

Dürmüller, U. 1989. „Attitudes towards English as a possible lingua franca in Switzerland", York Papers in Linguistics 14: 3-17.

Dürmüller, U. 1991. „Swiss multilingualism and intranational communication”, Sociolinguistica 5: 111-159.

Dürmüller, U. 1992. „The changing status of English in Switzerland” (w:) U. Ammon, M. Hellinger (eds.). Status change of languages. Berlin - New York: Mouton de Gruyter: 355-370.

Dürmüller, U. 1994. „Multilingual talk or English only? The Swiss experience”, Sociolinguistica 8: 44-64.

Dürmüller, U. 1997. Changing patterns of multilingualism. From quadrilingual to multilingual Switzerland. Zürich: Pro Helvetia.

Dürmüller, U. 2001. „The presence of English at Swiss universities” (w:) U. Ammon (ed.). The dominance of English as a language of science: effect on other languages and language communities. Berlin - New York: Mouton de Gruyter: 389-403.

Ferguson, Ch. 1972 [1959]. „Diglossia”, Word 15: 325-340. Reprinted in: Pier Paolo Gigliolo, Language and social context. Selected readings. Harmondsworth: Penguin Books: 232-251.

Graddol, D. 2001. „The future of English as a European language”, The European English Messenger 10 (2): 47-55.

Grin, F. 1997. „Language policy developments in Switzerland: needs, opportunities and priorities for the next few years", Swiss Political Science Review 3 (4): 108-113.

Grin, F. 1999. „Language policy in multilingual Switzerland: overview and recent developments", ECMI Brief No. 2 (March). Flensburg: European Centre for Minority Issues.

Haugen, E. 1959. „Planning for a standard language in modern Norway”, $A n$ thropological Linguistics 1 (3): 8-21.

Haugen, E. 1972. The ecology of language: essays. Selected and introduced by Anwar S. Dil. Stanford: Stanford University Press. 
Jernudd, B., das Gupta, J. 1971. „Towards a theory of language planning” (w:) J. Rubin, B. Jernudd (eds.). Can language be planned? Honolulu: University of Hawaii Press: 195-215.

Kloss, H. 1966. „Types of multilingual communities, a discussion of ten variables", Sociological Inquiry 36 (2): 135-145.

Kolde, G. 1988. „Language contact and bilingualism in Switzerland” (w:) Ch. B. Paulston. International handbook of bilingualism and bilingual education. New York: Greenwood Press: 517-537.

Linder, W. 1996. Demokracja szwajcarska: rozwiazywanie konfliktón w społeczeństwie wielokulturowym. Rzeszów: Wyższa Szkoła Pedagogiczna.

Lotherington, H. 2004. „Bilingual education” (w:) A. Davies, C. Elder (eds.). The bandbook of applied linguistics. Oxford: Blackwell: 695-718.

Murray, H., Dingwall, S. 1999. „The future of English in Switzerland: a majority/minority problem?", Bulletin suisse de linguistique appliquée 69 (2): 189-206.

Pap, L. 1990. „The language situation in Switzerland: an updated survey”, Lingua 80: 109-148.

Paulston, Ch. B. 1988. International handbook of bilingualism and bilingual education. New York: Greenwood Press.

Phillipson, R., Skutnabb-Kangas, T. 1996. „English only worldwide or language ecology?", TESOL Quarterly 30 (3): 429-452.

Porębski, Cz. 1994. Na praylkład S zwajcarzy .... eseje i rozmowy. Kraków: Znak.

Prcic, T. 2003. „Is English still a foreign language?”, The European English Messenger 12 (2): 35-37.

Ratajczak, M. 2004. Jak porozumiewaja sie S zwajcaray? Media w wielokulturowej Szwajcarii. Wrocław: Wydawnictwo Uniwersytetu Wrocławskiego.

Romaine, S. 1994. Language in society: an introduction to sociolinguistics. (2nd ed.). Oxford: Oxford University Press.

Schmid, C. L. 2001. The politics of language: conflict, identity and cultural pluralism in comparative perspective. Oxford: Oxford University Press.

Skutnabb-Kangas, T. 2003. „Linguistic diversity and biodiversity. The threat from killer languages" (w:) Ch. Mair (ed.). The politics of English as a world language: new horizons in postcolonial cultural studies. Amsterdam - New York: Rodopi: 31-52.

Steinberg, J. 1996. Why Switzerland? Cambridge: Cambridge University Press.

Szulc, A. 1999. Odmiany narodowe jezylka niemieckiego: geneza - rozwój - perspektyny. Rozprawy wydziału filologicznego, tom LXX. Kraków: PAU.

Watts, R. 1991. „Linguistic minorities and language conflict in Europe: learning from the Swiss experience" (w:) F. Coulmas (ed.). A language policy for the European Community: prospects and quandaries. Berlin: Walter de Gruyter: 75-101.

Watts, R. 1997. „Language policies and education in Switzerland” (w:) R. Watts, J. Smolicz (eds.). Cultural democracy and ethnic pluralism: multicultural and multilingual policies in education. Frankfurt: Peter Lang: 271-302. 
Polityka językowa w zakresie nauczania pierwszego języka obcego w wielojęzycznym...

Watts, R. 2001. „Discourse theory and language planning: a critical reading of language planning reports in Switzerland" (w:) N. Coupland, Ch. Candlin, S. Sarangi (eds.). Sociolinguistics and social theory. London: Addison Wesley Longman: 297-320.

Widmer, A., Laubscher, C., Fluegel, Ch. 1987. Herausforderung Schweiz. Materialien zur Förderung des Unterrichts in den Landessprachen. Bern: Schweizerische Konferenz der kantonalen Erziehungsdirektoren. 